\title{
A magyar rendészeti felsőoktatás jelene és jövője
}

\section{CHRISTIÁN László ${ }^{1 \oplus}$ - HAUTZINGER Zoltán² ${ }^{2 \oplus}$ - KOVÁCS Gábor ${ }^{3 \oplus}$}

\begin{abstract}
A Nemzeti Közszolgálati Egyetem létrejöttével a Rendészettudományi Karon folytatott rendészeti képzések új dimenzióba kerültek, amelyek fejlődése folyamatos és jól nyomon követhetö. A tanulmány röviden bemutatja a Karon végzett rendészeti felsőoktatás alap-és mesterképzési rendszerét, jelenlegi helyzetét, kilátásait, valamint felvillantja mindazokat a kezdeményezéseket is, amelyek átfogó jelleggel igyekeznek a rendészeti felsőoktatás számára új irányokat meghatározni.
\end{abstract}

Kulcsszavak: Rendészettudomány Kar, rendészeti felsőoktatás, rendvédelmi tisztképzés

\section{Rendészeti felsőoktatás az egyetemi térben}

A 2000-es évek kezdetén a katonai és rendvédelmi felsőoktatás rendszere meglehetősen kiterjedt volt. ${ }^{4} \mathrm{~A}$ honvédségi megrendelői igények folyamatos csökkenése miatt ezek az intézmények az állandó átalakulás eredményeként a Hungária körúti Zrínyi Miklós Nemzetvédelmi Egyetem bázisára koncentrálódtak. Az így formálódó katonai felsőoktatás elsősorban a határőrképzés terén kapcsolódott szervesen a rendészeti felsőoktatáshoz. A rendvédelmi felsőoktatás elsődleges bázisa természetesen a Rendőrtiszti Főiskola volt (RTF, Főiskola). A Főiskola képzéseinek folyamatos korszerűsítése révén az nemcsak a rendőrtisztek, hanem az egész rendészeti ágazat felsőfokú

\footnotetext{
Dr. habil. Christián László r. ezredes, Nemzeti Közszolgálati Egyetem Rendészettudományi Kar Magánbiztonsági és Önkormányzati Rendészeti Tanszék, tanszékvezető egyetemi docens, oktatási rektorhelyettes.

László Christián, PhD, habil, Police Colonel, University of Public Service, Faculty of Law Enforcement, Department of Private Security and Municipial Policing, Vice Rector, Associate Professor, Head of Department.

E-mail: Christian.Laszlo@uni-nke.hu

2 Dr. habil. Hautzinger Zoltán r. ezredes, Nemzeti Közszolgálati Egyetem Rendészettudományi Kar Bevándorlási Tanszék, tanszékvezető egyetemi docens, oktatási dékánhelyettes.

Zoltán Hautzinger, PhD, habil, Police Colonel, University of Public Service, Faculty of Law Enforcement, Department of Immigration, Vice Dean, Associate Professor, Head of Department.

E-mail: hautzinger.zoltan@uni-nke.hu

3 Dr. habil Kovács Gábor r. dandártábornok, Nemzeti Közszolgálati Egyetem Rendészettudományi Kar Rendészeti Vezetéstudományi Tanszék, tanszékvezető egyetemi tanár.

Gábor Kovács, PhD, habil, Police Brigadier-General, University of Public Service, Faculty of Law Enforcement, Department of Management Science, Professor, Head of Department.

E-mail: kovacs.gabor@uni-nke.hu

4 Zrínyi Miklós Nemzetvédelmi Egyetem három telephelyen (Budapest, Hungária krt., Üllői út - Bolyai János Katonai Műszaki Főiskolai Kar, Szentendre - Kossuth Lajos Hadtudományi Kar, Szolnok - Repülőtiszti Műszaki Főiskolai Kar), valamint a Rendőrtiszti Főiskola.
} 
végzettségű szakembereinek a képzési helyszínévé vált. A képzések minőségi fejlesztése elkerülhetetlenné vált, ami stratégiai szinten csakis egyetemi szinten történhetett meg.

\section{Az elözmények, az Egyetem megalapítása}

A katonai és rendvédelmi felsőoktatás átalakításának gondolata, a szakemberszükséglet, a takarékossági megfontolások, az erőforrások összpontosítása miatt 2010-re érett be az átalakítás szükségessége. A teljes magyar felsőoktatás akkori szerkezete nem kellően tükrözte az Európában elfogadott normákat. Hazánkban nagyságrendekkel több felsőoktatási intézmény működött, mint amennyire szükség lett volna. Ebbe a komplex folyamatba illett bele a Nemzeti Közszolgálati Egyetem (NKE, Egyetem) létrehozása.

A szervezetalapítási szándékot a tettek követték. 2010 júniusában a Belügyminisztérium, a Honvédelmi Minisztérium, a Közigazgatási és Igazságügyi Minisztérium, valamint az érintett felsőoktatási intézmények képviselőiből munkabizottság alakult, amelynek feladata a Rendőrtiszti Főiskola, a Corvinus Egyetem Közigazgatás-tudományi Kara és a Zrínyi Miklós Nemzetvédelmi Egyetem integrációjának előkészítése volt. A bizottság előzetesen egy nagybani elgondolást fogadott el az Egyetem létrehozására vonatkozóan. A munka megkezdéséhez szükséges kormányhatározatot három albizottság (képzés-kutatási, szervezeti-vezetési és infrastruktúra-finanszírozási, jogi-felügyeleti albizottság) alkotta meg.

Az NKE-t az a felismerés hozta létre, hogy a közszolgálaton belül a rendvédelem, a polgári közigazgatás, a honvédelem és a nemzetbiztonsági szolgálatok személyi állományának képzése közös alapokon nyugszik. Ezzel összefüggésben a közös hivatástudat, valamint a szakértelem erősítése összehangolt és tervezett utánpótlásképzést igényel, amely hatékonyan és költségtakarékosan megvalósítható egy egyetem szervezeti keretein belül. ${ }^{5}$

Az NKE létesítéséről szóló 2011. évi XXXVI. törvényt ${ }^{6}$ március közepén fogadta el az Országgyưlés. E törvény meghatározta a létesítésben közremúködő és a résztvevő intézmények, testületek feladatait, működésének alapvető szabályait, valamint rendelkezett a megvalósítás ütemtervéről. Az NKE 2012. január 1-jén jött létre a fentebb említett felsőoktatási intézmények általános jogutódjaként.

5 Kovács Gábor: Tájékoztató a Nemzeti Közszolgálati Egyetem megalakulásáról és müködéséről. Migráció és Társadalom, (2012). 2.

6 Az egyetem létesítéséről szóló 2011. évi XXXVI. törvényt március 28-án fogadta el az Országgyủlés. (Ez a nap lett az Egyetem Napja). 2011. évi XXXVI. törvény a Nemzeti Közszolgálati Egyetem létesítéséről. 


\section{Az oktatási környezet jellemzói és hatásai}

Az NKE Rendészettudományi Karán (RTK) tanuló rendvédelmi ágazathoz tartozó hivatásrendeknek szakmai jellegükből adódóan jelentős országos vonzerejük van, ami jellemzően abban testesül meg, hogy a végzést követően a későbbi elhelyezkedési, munkába állási lehetőségek biztosítottak. Megjegyzendő, hogy a friss diplomások a szolgálat érdekében az ország bármely területére beosztásba helyezhetők.

\section{Az egyetem vezetési rendszere}

Már az egyetem alapításának előkészítésekor mindhárom fenntartó - megrendelőként - pontosan ismertette igényeit. A két fegyveres fenntartó szervezet, a Honvédelmi Minisztérium és a Belügyminisztérium teljes egészében meghatározta az érintett karok képzési profilját és a képzési kapacitásokat.

2012. július 3-án elkészült az Egyetem Szervezeti és Múködési Szabályzata,7 amely meghatározta az egyetem szervezeti és vezetési rendjét, a testületek és bizottságok rendszerét, a központ és a karok kapcsolatrendszerét, a funkcionális feladatok megosztását. Az egyetem felső vezetőiből álló Rektori Tanács heti rendszerességgel egyeztetett a Szenátus elé kerülő ügyekről, egyidejúleg bekérte a Kari Tanácsi véleményeket is. Az egyetem sajátosságaként jelentkezett, hogy a Szenátus döntéseinek jelentős részéhez a három fenntartó miniszter képviselőiből álló Fenntartói Testület konszenzuson alapuló jóváhagyása volt szükséges. Az egyetem előkészítésének és alapításának időszakában nagyon szoros volt az egyetem és a fenntartói közötti kapcsolat.

\section{Az oktatási, képzésfejlesztési törekvések fö irányvonala}

$\mathrm{Az}$ egyetem képzési portfóliója összességében átfogó, hiszen abban megtalálhatók az alapképzések, mesterképzések, doktori képzések, szakirányú továbbképzések, felsőfokú szakképzések és az átképzések. Az egyetem oktatási stratégiai célkitűzése az volt, hogy a közigazgatási, a rendészeti, a katonai és a nemzetbiztonsági felsőoktatásban többciklusú, autonóm és többkarú egyetemként megfeleljenek a fenntartó minisztériumok követelményeinek, valamint megőrizzék és továbbfejlesszék a jogelőd szervezetek értékeit és hagyományait. Feladatként jelentkezett a versenyképes szakmai tudás biztosítása, a nemzeti, az európai és a szövetségesi értékek iránt elkötelezett közigazgatási, rendészeti, honvédelmi és nemzetbiztonsági értelmiség nevelése, az egyetem tudományos-szellemi központ jellegének növelése, a tudományos kutatások gyakorlatorientáltságának biztosítása.

NKE SZMSZ www.uni-nke.hu/document/uni-nke-hu/szmsz-2012-i-1-2012-iv-18.original.pdf 
Az új képzési struktúra bevezetése érdekében, 2012-ben már nem indultak el a korábban kialakított, de a profilhoz közvetlenül nem illeszkedő képzések. Mindhárom fenntartói szervezet közös elvárása megegyezett a közös egyetemi modul létrehozásával, közös célként jelentkezett a közszolgálati életpályák közötti átjárhatóság megteremtése. A közös egyetemi modul kialakítása, illetve tantervbe iktatása 2013 szeptemberére mindhárom karon megtörtént. E mellett feladat volt még az alapés mesterszakok és a doktori képzések, valamint a tantárgyi struktúra és a tantervi háló összehangolása. A közszolgálati szemléletmód és attitűd kialakításának meghatározó eszközévé lépett elő az évente levezetett „Közös közszolgálati gyakorlat”, amely lehetőséget biztosított az egyetemen tanuló hallgatók számára a közös feladatok megoldására, a közös felelősségvállalásra, a megszerzett szakmai ismeretek gyakorlatban történő közös alkalmazására.

\section{Az oktatókkal szemben támasztott követelmények}

Az egyetem karai által gondozott speciális és aktuális tananyagok, képzési területek megkövetelték, hogy az adott tantárgy anyagát a szakfelelősök, a szakirányfelelősök és a tantárgyak oktatói folyamatosan frissítsék és aktualizálják. Az egyetem vezetésének folyamatos elvárása volt, hogy az oktatók saját szakterületükön és a képzést érintő kérdésekben aktuális tudással rendelkezzenek és azt folyamatosan fejlesszék. A képzési szakfejlesztési fórumok lehetőséget biztosítottak a megrendelői oldal igényei, elvárásai megismerésére, ennek eredményeként a képzés rendszere és tartalma korszerúvé vált, igazodott az igényekhez.

\section{A magyar rendészeti felsőoktatás rendszere}

A rendészeti felsőoktatás egyetemi keretek közé szervezése, a Rendészettudományi Kar megalakulása a rendészeti felsőoktatás történetében ugyanolyan mérföldkőnek számít, mint amilyen az 1970-es években a Rendőrtiszti Főiskola létesítése volt. A főiskolai jogutódként működő karon folyó alap-, mester- és doktori képzés összessége jelenti ugyanis napjainkban a magyar rendészeti felsőoktatás komplex rendszerét. Ez egyúttal a felsőoktatás primátusát is magában foglalja, mivel Magyarországon egyetlen más felsőoktatási intézményben sem hirdethetnek meg olyan képzést, amely rendészeti (rendőri, katasztrófavédelmi stb.) alapképzettséget biztosít. Emellett a Rendészettudományi Kar az ország egyetlen olyan felsőoktatási intézménye, amely kizárólagos jogkörben, valamennyi, a rendvédelmi szférában tiszti kinevezés alapjául szolgáló képzést a képzési portfóliójában tudhatja. Ez azt is jelenti, hogy a más főiskolai vagy egyetemi oklevéllel rendelkező, a rendvédelmi hivatást választó személyek számára is csak e karon keresztül vezethet az út a tiszti kinevezés megszerzéséhez. 


\section{A rendészeti felsőoktatás alrendszerei}

A rendészeti felsőoktatás rendszerének jelenlegi arculata az úgynevezett bolognai folyamat eredményeként a 21. század első évtizedében alakult ki. A 2006. évtől ugyanis - Virányi Gergely elemzésén alapulva - a bolognai folyamatból adódó kötelezettségekből fakadóan felmenő rendszerben lineáris és többciklusú felsőoktatás kezdte meg múködését a rendészeti területen:

„A korszerűsített rendészeti felsőoktatás a jogi és igazgatási képzési területen, az igazgatási képzési ágban rendszerbe illesztett rendészeti képzési programokat fogja össze. Az EU-kompatibilis rendészeti felsőoktatás első képzési főciklusában (bachelor) felsőoktatási alapfokozatot és felsőfokú rendészeti szakképzettséget lehet szerezni. Az elsőre épülő második képzési fő́ciklus (master) mesterfokozatot és az azt igazoló rendészeti mesteroklevelet eredményez, és ezzel megvalósul a rendészeti felsőoktatásban a mintegy másfél évtizede jogosan hiányolt szakmai »egyetemi kimenet“. A későbbi harmadik képzési főciklusban doktori (PhD) fokozatot lehet majd elnyerni." ${ }^{8}$

A rendészeti felsőoktatás jelenlegi képzési rendszere tehát már az egyetemi integrációt megelőzően elnyerte mai arculatát, de azt abban az időben nemcsak egy széleskörúen hozzáférhető, két különböző szakon mindösszesen kilenc szakirányon elérhető, rendészeti alapképzettséget biztosító képzés jellemezte, hanem egy meglehetősen korlátozottan hozzáférhető mesterképzési szak is. Emellett a rendészettudományi doktori képzés feltételei sem álltak fenn, ennélfogva ennek a képzési főciklusnak a megvalósulása a főiskolai státuszban mint megoldhatatlan feladat jelentkezett. Mindezekkel összefüggésben az egyetemi integrációt követő időszakra hárult mindazoknak a fejlesztéseknek a véghezvitele, amelyeknek az egyes alrendszerek (alapképzés, mesterképzés) gazdagítása, másfelől a doktori képzés kialakításával teljessé vált a rendészeti felsőoktatás rendszere.

\section{A rendészeti alapképzési alrendszer}

Túlzás nélkül állítható, hogy a rendészeti felsőoktatás rendszerén belül az alapképzési alrendszer a legkomplexebb. Egyrészt ez a rendszer határozza meg a Rendészettudományi Kar tanszéki struktúráját, másrészt az alapképzés - egyúttal mint szakképzettséget is biztosító képzés - a lehető legszerteágazóbb módon érinti a rendészet szinte valamennyi területét. Ezzel összhangban az alapképzés kiterjed az adó- és vámhivatali (pénzügyőr), a büntetés-végrehajtási, a katasztrófavédelmi, a polgári nemzetbiztonsági, nem utolsósorban rendőri szervezetek tiszti utánpótlásának biztosítására.

8 Virányi Gergely: Határrendészeti tisztképzés a Rendôrtiszti Fôiskolán, 1971-2011. Budapest, Dialóg Campus, 2019. 449. 
A képzések rendszere az alábbiak szerint épül fel, az egyes képzési szintek egymással összefüggő rendszert alkotnak.

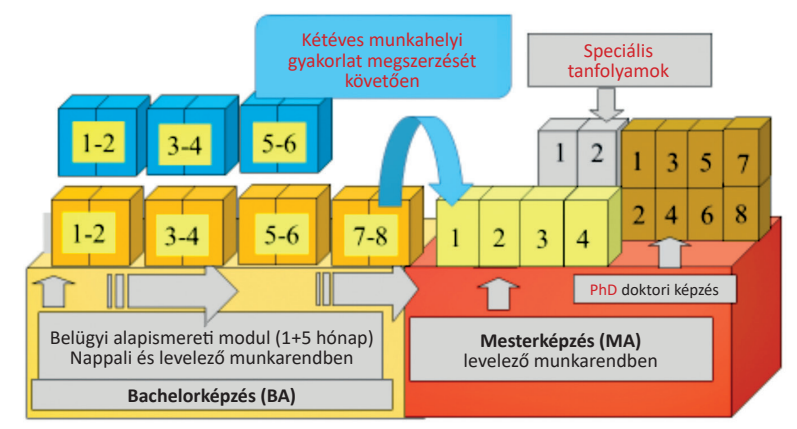

1. ábra: A képzések rendszere a Rendészettudományi Karon

Forrás: a szerzők szerkesztése

Mindezekre figyelemmel a rendészeti alapképzési alrendszer az alábbiak szerint vázolható fel:

- Bûnügyi igazgatási alapképzési szak (hároméves képzési időben, többnyire levelező munkarendre hirdetve):

- Bünügyi hírszerző szakirány;

- Bünügyi nyomozó szakirány (nappali munkarendre is hirdetve);

- Gazdaságvédelmi nyomozó szakirány;

- Informatikai nyomozó szakirány;

- Pénzügyi nyomozó szakirány;

- Rendészeti igazgatási alapképzési szak (hároméves képzés időben, többnyire levelező munkarendre hirdetve):

- Biztonsági szakirány;

- Büntetés-végrehajtási szakirány;

- Határrendészeti szakirány (nappali munkarendre is hirdetve);

- Igazgatásrendészeti szakirány;

- Közlekedésrendészeti szakirány;

- Közrendvédelmi szakirány (nappali munkarendre is hirdetve);

- Migrációs szakirány;

- Vám- és jövedéki igazgatási szakirány;

- Bünügyi alapképzési szak (négyéves képzési időben, kizárólag nappali munkarendre hirdetve):

- Adó- és pénzügyi nyomozó szakirány;

- Bűnüldözési szakirány;

- Bűnügyi felderítési szakirány;

- Gazdasági nyomozó szakirány;

- Kibernyomozó szakirány; 
- Rendészeti alapképzési szak (négyéves képzési időben, kizárólag nappali munkarendre hirdetve):

- Bevándorlási szakirány;

- Határrendészeti rendőr szakirány;

- Igazgatásrendészeti rendőr szakirány;

- Közlekedésrendészeti rendőr szakirány;

- Közrendvédelmi rendőr szakirány;

- Vám- és pénzügyőr szakirány;

- Katasztrófavédelem alapképzési szak (hároméves képzés időben, levelező és nappali munkarendre is hirdetve):

- Iparbiztonsági szakirány;

- Katasztrófavédelmi múveleti szakirány;

- Tüzvédelmi és mentésirányítási szakirány;

- Polgári nemzetbiztonsági alapképzési szak (hároméves képzési időben, kizárólag levelező munkarendre hirdetve):

- Terrorelhárítási specializáció;

- Technikai felderítő specializáció;

- Humán felderítő specializáció.

Az alapképzési szakok együttes jellemzője, hogy azok mindegyike - mint a rendészeti felsőoktatás alapképzési alrendszere - egyúttal az államtudományi képzési ág keretében, ezáltal egy nagyobb, a katonai, a közigazgatási és a rendészeti felsőoktatási területhez is kapcsolódik. Ez az egyes szakirányok esetében úgy jelentkezik, hogy mindegyik tantervében - az Államtudományi és Nemzetközi Tanulmányok Karon folyó közigazgatási, illetve nemzetközi, valamint a Hadtudományi és Honvédtisztképző Karon zajló katonai képzések tanterveihez hasonlóan - megjelenik az úgynevezett Ludovíceum tantárgycsoport. Ezek ismeretanyagában egyaránt megtalálható a hagyománytisztelet és az általános műveltség, kultúra és értékek fejlesztése, de ez a tantárgycsoport felelős azért is, hogy az államtudomány és a közszolgálatiság számos elemével is megismerkedhessenek a hallgatók. Ez utóbbi kategóriához tartoznak az állam és kormányzás, a honvédelem, az európai tanulmányok, a nemzetközi politika és biztonság, a fenntartható fejlődés és az információs társadalom.

Természetesen az alapképzés hangsúlyosabb részét azok a kurzusok jelentik, amelyek a rendészeti (rendőri) szakképesítés megszerzéséhez elengedhetetlenek. Ezek egy része közös ismeretanyagként az általános szolgálati ismeretekhez és képességekhez, illetve rendészetelméleti és történeti tudnivalókhoz kapcsolódik, másik része pedig a szakrendészeti (bűnügyi, bûnüldözési, gazdaságvédelmi, informatikai bûnüldözői, valamint büntetés-végrehajtási, határrendészeti, idegenrendészeti-bevándorlási, igazgatásrendészeti, közbiztonsági, közlekedésrendészeti, pénzügyi rendészeti és nyomozói, katasztrófavédelmi stb.) tudásbázis bővítéséért felelős.

A rendészeti tudásbázis biztosításáért a kari tanszéki szervezetek a felelősek. Ennélfogva a rendészeti felsőoktatásért felelős tanszékek: Bevándorlási Tanszék, 
Büntetés-végrehajtási Tanszék, Büntetőjogi Tanszék, Büntető-eljárásjogi Tanszék, Bűnügyi, Gazdaságvédelmi és Kiberbűnözés Elleni Tanszék, Forenzikus Tudományok Tanszék, Határrendészeti Tanszék, Idegennyelvi és Szaknyelvi Lektorátus, Igazgatásrendészeti és Nemzetközi Rendészeti Tanszék, Közbiztonsági Tanszék, Kriminálpszichológiai Tanszék, Kriminológiai Tanszék, Magánbiztonsági és Önkormányzati Rendészeti Tanszék, Nyomozáselméleti Tanszék, Rendészetelméleti és -történeti Tanszék, Rendészeti Magatartástudományi Tanszék, Rendészeti Vezetéstudományi Tanszék, Terrorelhárítási Tanszék, Testnevelési és Küzdősportok Tanszék, Vámés Pénzügyőri Tanszék.

E tanszékek önálló kari oktatási szervezeti egységekként működnek. Mellettük kap még helyet a Katasztrófavédelmi Intézet, amelyen megtalálható az Iparbiztonsági Tanszék, a Katasztrófavédelmi Műveleti Tanszék és a Tűzvédelmi és Mentésirányítási Tanszék. Sajátos karközi intézményként kapcsolódik még a rendészeti felsőoktatáshoz a Nemzetbiztonsági Intézet két tanszéke: a Polgári Nemzetbiztonsági Tanszék, illetve a Terrorelhárítási Tanszék. Végül, az oktatási és a kiképzési feladatok sajátos megvalósításáért felel még a Rendészeti Kiképzési és Nevelési Intézet, amely szervezeti egységben kap helyet a nappali munkarendes hallgatók rendészeti szocializációjáért felelős Rendvédelmi Tagozat is.

\section{A rendészeti mesterképzési alrendszer}

Az egyetemi minőség legfontosabb közvetítői az egyes mesterképzési szakok. Ezek sorában - főiskolai időkben elindult rendészeti vezető mesterképzési szak mellé - immár a Rendészettudományi Karra akkreditálták a biztonsági szervező, a kriminalisztikai, a katasztrófavédelmi vagy éppen a polgári nemzetbiztonsági mesterképzési szakokat. Ezek - valamint az alapképzések - révén a rendészeti egyetemi képzés napjainkban lefedi a rendészeti igazgatáshoz, a bűnügyi munkához, a rendészetelmélethez, nem utolsósorban az egyes szakrendészetekhez kötődő képzési területeket. Emellett a 21. század harmadik évtizedére szinte minden rendészeti gyakorlatot folytató, felsőoktatási oklevéllel rendelkező munkatársa számára elérhetővé vált az egyetemi diploma megszerzése a rendészettudomány keretein belül.

A Rendészettudományi Kar mesterképzési szakjai:

- Biztonsági szervező mesterképzési szak;

- Katasztrófavédelem mesterképzési szak;

- Kriminalisztika mesterképzési szak:

- Rendészeti szakirány;

- Polgári szakirány;

- Polgári nemzetbiztonsági mesterképzési szak:

- Humán felderítő specializáció;

- Technikai felderítő specializáció;

- Terrorelhárítási specializáció; 
- Rendészeti vezető mesterképzési szak:

- Rendészetelméleti specializáció;

- Csapatszolgálati specializáció;

- Értékelő-elemző specializáció;

- Szervezett bűnözés elleni specializáció;

- Integrált határigazgatási specializáció.

Az egyes mesterképzési szakok létjogosultsága - a megfogalmazott képzési célok mellett - azon is múlik, hogy milyen többletismeretet adhatnak az alapképzésen nyújtott képzésekhez képest. A mesterképzésekben ezen túlmenően nemcsak új ismeretek átadására, hanem a meglévő tudás szakmai tartalmának növelésére, az egyes gyakorlati kompetenciák továbbfejlesztésére is törekedni kell. Az egyes mesterképzési szakok múködtetése mindazonáltal sajátos szervezeti megvalósítási igénnyel nem él. Az oktatás a fentebb ismertetett tanszéki keretek között folyik azzal, hogy ebben az alrendszerben nem kap szerepet a Rendészeti Nevelési és Kiképzési Intézet.

\section{A rendészettudományi doktori képzés alrendszere}

A rendészettudományi képzés legfontosabb jelenkori eredménye kétségtelenül a Rendészettudományi Doktori Iskola megalapítása volt, amely egyúttal felfogható volt egy meglévő tudományos igényre adott megfelelő válasznak, de szakmai hiátus pótlásának is, amely elengedhetetlen e tudományág önálló fejlődéséhez. ${ }^{9}$ A rendészettudomány területén e doktori iskola múködését megelőzően is folytak kutatások, de ezek nem a rendészettudományi ismeretek bázisán, hanem olyan doktori iskolákban (különösen a Hadtudományi Doktori Iskolában, Katonai Műszaki Doktori Iskolában, jogtudományi doktori iskolákban stb.), amelyek tudományos profiljai kapcsolódhattak a rendészethez vagy magához a rendészettudományhoz. A Rendészettudományi Doktori Iskola létrejöttével teljesült a rendészeti vezető mesterképzési szak 2008-as megindításakor kitűzött egyik kiemelt cél: a mesterképzéssel megteremteni a Rendészettudományi Doktori Iskolai képzés rendészeti mesterképzési bemenetét.

A Rendészettudományi Kar képzésfejlesztési törekvéseinek eredményeként 2016. február 1-jén - Magyarország viszonylatában egyedüliként - megalakult a Rendészettudományi Doktori Iskola, ezzel megteremtve azt a kiváló lehetőséget, hogy a rendészeti vezető mesterképzési szakon diplomát szerzett hallgatók immár tovább folytassák tanulmányaikat a PhD-fokozat megszerzésére.

9 Kerezsi Klára - Pap András László: Rendészet, tudomány, doktori iskola. Magyar Rendészet, 15. (2015), 4. 76. 
A Rendészettudományi Doktori Iskolában a következő kutatási területekhez lehet csatlakozni:

- általános rendészetelmélet, rendészettörténet, nemzetbiztonság és rendészet;

- szakrendészetek, a rendészet európai uniós és nemzetközi vonásai;

- a rendészet jogi, kriminológiai, kriminalisztikai és társadalomtudományi aspektusai.

A rendészettudományi doktori képzés a rendészeti felsőoktatás rendszerének egy sajátos alrendszere is, hiszen a doktori képzés kevésbé a hagyományos iskolarendszerü oktatás színterén jelenik meg, sokkal inkább az egyéni kutatáson, a doktorandusz és a témavezető tudományos együttmüködésén. Ezzel együtt ugyanakkor a rendészeti felsőoktatás csak így lehet teljes, és így tud hozzájárulni a rendészettudomány akkreditációjához. ${ }^{10}$

\section{Az NKE RTK oktatói és hallgatói kollektívája, a szakmai felkészítés}

A Kar oktatói és hallgatói kiváló közösséget alkotnak, amelyben a közösen végzett oktató-nevelő munka során megvalósul a teljes oktatási folyamat. Az oktatók magas szintű szakmai és pedagógiai felkészültsége, az oktatók és hallgatók kedvező aránya biztosítja a hatékony és naprakész ismeretátadást, a 21. századi követelményeknek történő megfelelést.

\section{A Kar oktatói}

Összesen az RTK-n 139 fő hivatásos és 120 fő közalkalmazott dolgozik, ez mindöszszesen 259 fő. A Karon 102 fő vezényelt hivatásos/kirendelt oktató dolgozik, ebből 48 fő - 47, 05\% rendelkezik tudományos fokozattal. Ebből az állományból 3 fő egyetemi tanár, 22 fő egyetemi docens. A habilitált oktatók száma 9 fő, jelenleg 1 fő eljárása van előkészületben. Viszonylag magas a mesteroktatók száma: 23 fő.

A közalkalmazotti állományt összesen 56 fő alkotja, ebből 33 fő - 59\% rendelkezik tudományos fokozattal. Ebben az állománykategóriában 8 fő egyetemi tanár és 13 fő egyetemi docens dolgozik a karon. A mesteroktatók száma 14 fő. A Karon egy hivatásos állományú kutató és 3 fő közalkalmazott kutató dolgozik. A két oktatói állománycsoport összesítése alapján 51,2\%-nak van tudományos fokozata. Az RTK munkáját hat fő professzor emeritus segíti.

Az RTK aktív állományában lévő MTA-doktorok: Papp András, Kerezsi Klára, Haller József.

10 Sallai János: A magyar rendészettudomány akkreditációja. Belügyi Szemle, (2019), 10. 22. 


\section{A karon tanuló hallgatói állomány összetétele}

A Karon jelenleg összesen 1948 fő hallgató és 56 doktorandusz folytat tanulmányokat. A nappali alapképzésben 622 fő tanul. Ebből tisztjelölt 469 fő, tiszthelyettes 36 fő, a biztonsági szakirányon 75 fő, a migrációs szakirányon 25 fő, a BV szakirányon 17 fő folytat tanulmányokat. A levelező munkarendes képzésben, az alapképzésben 751 fő, a mesterképzésben 270 fő, a szakirányú továbbképzésben 305 fő tanul.

A Rendészettudományi Doktori Iskolában nappali munkarendes képzésben 11 fö, levelező munkarendes képzésben 45 fő tanul. Az összes hallgatói létszám: 56 fő. ${ }^{11}$

\section{A hallgatók szakmai felkészítésével, nevelésével kapcsolatos tervek}

A Kar a teljes rendvédelmi szféra részére, a négyes feladatrendszer végrehajtásával - amely a kiképzés (a tisztjelöltek alapfelkészítése), a nevelés (a tisztjelöltek hivatásrendi felkészítésének egyik eszköze), a képzés (a gyakorlatorientált felkészítés) és az oktatás (az általános értelmiségi felkészítés és a szakmai ismeretek elsajátítása) - a 21. századi kihívásokra készíti fel a hallgatókat, azzal a céllal, hogy megfeleljenek a magas szintű szakmai és társadalmi elvárásoknak.

Mindezen feladatok végrehajtása mellett a Kar célja, hogy - a nemzeti hagyományok ápolásának szem előtt tartása mellett - felkészítse a tisztjelölteket a legitim erő demokratikus társadalmi viszonyok között történő alkalmazásának politikai, szociológiai, kriminológiai, pszichológiai, jogi és etikai vonatkozásaira is.

\section{A kutatással kapcsolatos célkitúzések és a kutatás fő irányai}

A Kar oktatói és kutatói jelentős gyakorlattal rendelkeznek a rendészettudományi kutatások körében. A tudományos kutatások fő irányainak meghatározása során a kar vezetése messzemenően figyelembe vette a rendvédelmi szervezetek kutatásfejlesztési igényeit.

\section{Az RTK állományának jövóbeni kutatási feladatai}

Az NKE RTK állománya a jövőben aktív szerepet vállal a tudományos kutatások végrehajtásában.

\footnotetext{
11 Forrás: NKE Humán Igazgatóság 2021. május 14-ei adatok.
} 
Biztonsági TechnológiákNemzetiLaboratórium programban Magyarország NemzetiBiztonsági Stratégiáját követve [1163/2020. (IV. 21.) Korm. határozat] a technológiaalapú biztonság három pillérének (az intézménybiztonság, a településbiztonság és az ország/határbiztonság) integrált kutatását és a kapcsolódó innovációkat célzó programok országos hatókörű kutatóhelye jött létre. A Nemzeti Laboratórium a biztonságtechnológiai kutatásoknak olyan átfogó szemléletű és nyitott kutatási kereteként működik, amelyben a hazai kutatásokat az európai szintű kutatási és pályázati hálózatépítésbe nagyobb eséllyel lehet bekapcsolni, biztosítva egyben a tudományos hátteret és egyetemi infrastruktúrát is. A belbiztonsági kutatási-fejlesztési irányok meghatározása mellett, a projekt kiemelt célja olyan kézzelfogható és piaci értékkel rendelkező innovációk létrehozása, amelyek a magán- és a közbiztonsági szektorban egyaránt hasznosíthatók.

Fenntartható biztonság és társadalmi környezet projekt - amelyben megtörténik az egyetem, ezzel együtt a Kar szakmai és tudományos kiválóságának megalapozása. A kutatás eredményeként olyan tudományos múvek, termékek, szolgáltatások, szabályozások és oktatási tematikák jönnek létre, amelyek a hazai felsőoktatás kínálatán keresztül mind a hazai, mind a külföldi érdeklődők számára relevánsak, és a magyar jogrendben, összhangban az európai szabályozási célokkal a hazai és európai piacon jelennek meg.

Stratégiai feladatként jelentkezik a meglévő Kriminálpszichológiai Kutatómúhely támogatása, szakmai igény esetén újak alapítása, valamint a Rendvédelmi (Belbiztonsági) Kutatóintézet (munkanév) létrehozása, amelyben az RTK-nak jelentős szerepet kell vállalnia.

Korunk kihívása az informatikai fejlesztések és a mesterséges intelligencia bevonása a rendészeti feladatokba, ez a jövő egyik legfontosabb kutatási iránya lesz - az RTK tanszékeinek ebben a témakörben is az élen kell járnia.

\section{A rendészettudományi kutatások fö irányai}

A rendészettudományban az NKE RTK hazánk egyetlen kutatóhelye. A megkezdett fejlesztések nyomán stratégiai területek: kriminalisztika (krimináltechnika, krimináltaktika és -metodika), a forenzikus tudományok; a kriminálpszichológia; a rendészeti képességek mérése; a közbiztonság szociológiája; a magánbiztonság; rendészeti vezetés és szervezéselmélet; a mesterséges intelligencia alkalmazása a rendészetben; az antikorrupciós kutatások - a Nemzeti Védelmi Szolgálattal együtt; migráció rendészeti vonatkozásai; a nemzetközi külszolgálati missziók tapasztalatai, minősített időszakokra vonatkozó rendészeti tevékenység. 


\section{A rendészeti felsőoktatás helyzetértékelése és lehetséges jövőképe}

$\mathrm{Az}$ amerikai Police Executive Research Forum (Rendőri Vezetők Kutatási Fóruma) két éve készített jelentésében rámutat arra, hogy „jelenleg a rendészeti hivatás munkaerőválsággal kényszerül szembenézni”, ${ }^{12}$ ugyanis az elmúlt években egyre kevesebben választják a rendészeti hivatást, miközben egyre többen vannak azok, akik néhány év után elhagyják a pályát. Wilson és Grammich szerzőpáros már az ezredfordulót követő évtized végén felhívták a figyelmet arra, hogy a 21. század rendészeti szerveket érintő két legnagyobb kihívását a toborzás és a megtartás jelentheti. A hivatkozott szerzők szerint a babyboom-generáció nyugdíjba vonulása, a költségvetési források szűk keresztmetszete, a jó képességű és képzett jelentkezőkért folyó verseny, valamint a fiatal generáció tagjainak a munkához való újszerű viszonyulása jelentősen kiélezi ezt a kihívást. ${ }^{13}$ Az Egyesült Államok Igazságügyi Minisztériumának átfogó helyzetértékelése külön kiemelte azokat a szakmai és társadalmi tényezőket, amelyek jelentősen megnehezíthetik a rendészeti szervek toborzási tevékenységét. A szaktárca összefoglalója szerint az új alkalmazottak állományba felvételéhez kapcsolódóan a rendészeti szervek olyan kihívásokkal kénytelenek szembenézni, mint:

- a szervezetek közötti verseny;

- szolgálatok hossza, túlóra, kiégés;

- a sajátos szervezeti kultúra;

- egyes rendészeti ágazatokat érintő negatív társadalmi viszonyulás;

- a nők felvételét korlátozó eljárások és politika;

- a droghasználattal kapcsolatos politika; ${ }^{14}$

- az új generációt célzó toborzási stratégia és márkaépítés hiánya, amely során reálisan mutatják be az adott bűnüldöző szerv tevékenységét;

- a rendészeti szervek által szolgált közösségekkel kialakított partnerség hiánya;

- hosszadalmas, idejétmúlt koncepciókon és technológián alapuló jelentkezési folyamatok. ${ }^{15}$

Európai viszonylatban a rendészeti szervek állományát illetően stabilitásrólárulkodnak a statisztikai adatok. Az Európai Unió 27 vizsgált tagállamában 1999 és 2018 között a rendőri szervek állományának létszáma stagnál. ${ }^{16} \mathrm{~A}$ képet ugyanakkor árnyalja

12 Police Executive Research Forum: The workforce crisis, and what police agencies are doing about it. Washington D. C., (September 2019) 7.

13 Jeremy M. Wilson - Clifford A. Grammich: Police recruitment and retention in the contemporary urban environment. RAND Corporation, Santa Monica, CA, 2009. 3.

14 A marihuána legalizációjával egyidejúleg például a Washingtoni Rendőr-főkapitányság (Washington, D.C., Metropolitan Police Department) Kadét Programjába felvételizők esetében, a marihuánafogyasztás tilalmának vizsgálati időszakát a jelentkezést megelőző három évről egy évre csökkentették. Kevin P. Morison: Hiring for the 21st century law enforcement officer: Challenges, opportunities, and strategies for success. Washington, D.C.: Office of Community Oriented Policing Services, 2017. 15.

15 Office of Community Oriented Policing Services: Deliberative and pre-decisional. Chapter 2. Law Enforcement Recruitment and Training. Washington D.C., The United States Department of Justice, 2020.

16 Eurostat: Police, court and prison personnel statistics. Eurostat, 2020. 
az a körülmény, hogy az unió lakossága az elmúlt közel hat évtizedben 106 millió fővel, 26\%-kal gyarapodott. ${ }^{17}$ A lakosság számához arányosítva tehát az európai szervek helyzete sem tehermentes. Ezzel együtt pedig a rendészeti szervek állományának diverzitásában is jelentős elmaradások vannak. A nők vagy a bevándorló családi háttérrel rendelkezők aránya jóval elmarad az átlag lakosságban képzett arányuktól. Az európai átlagot tekintve például a női rendőrtisztek aránya jelentősen elmarad az 50\%-tól. ${ }^{18}$

Az elmúlt egy évtizedben számos hazai rendészettudományi kutatás is foglalkozott a magyar rendészeti szerveket érintő humánpolitikai kihívásokkal, úgymint a létszámhiány, a pályakezdők toborzásával, bevonzásával és az elvándorlással kapcsolatos nehézségek. A kutatási eredmények összességében arra engednek következtetni, hogy a nemzetközi tapasztalatokhoz hasonlóan a toborzás és megtartás az elmúlt évtizedek egyik legfontosabb kihívásaként jelentkezik a magyar rendőrség, ${ }^{19}$ a büntetés-végrehajtási szervezet, ${ }^{20}$ a katasztrófavédelem ${ }^{21}$ és a vámhatóság ${ }^{22}$ esetében egyaránt. Egyes hazai vizsgálatok szerint napjainkban a magyar rendészeti szervek esetében a személyi állomány részleges elvándorlása eleve prognosztizálható, ezzel együtt pedig az utánpótlást jelentő új generáció tagjai csak korlátozott számban toborozhatók a rendészeti hivatásra. ${ }^{23}$

Témánk kapcsán meghatározó szerepe van a magyar rendészeti felsőoktatás helyzetértékelésének, hiszen ezen a képzési területen monopolhelyzetben lévő NKE RTK a rendészeti szervek tiszti állományának jelentős utánpótlásbázisát adja. ${ }^{24} \mathrm{Mi}$ több, ennek a szellemi múhelynek a hallgatói révén biztosítható egy olyan rendészeti értelmiségi utánpótlás, amely a szükséges rendészeti szocializáció mellett magas fokú jogi és szakmai felkészültséggel rendelkezik. Az NKE Rendészettudományi Karon folyó képzés jelentősége, valamint monopolhelyzete ellenére, az elmúlt évek jelentkezési

17 KSH: Népesedési világnap, 2019. július 11. Statisztikai Tükör, Budapest, Központi Statisztikai Hivatal (2019. július 11.).

18 Anne R. van Ewijk: Diversity within Police forces in Europe: A case for the comprehensive view. Policing, 6. (2011), 1. 78.

19 Bartos László: Gondolatok a rendészeti oktatásról. Rendészeti Szemle, 57. (2009), 3. 3-15; Christián László: A helyi rendészeti együttműködés rendszere. Iustum Aequum Salutare, 14. (2018), 1. 33-61; Vári Vince: A rendőri életpályamodell és a rendőri felsőoktatás összehangoltsága. Magyar Rendészet, 18. (2018), 2. 205-222.

20 Kiskopárdi Zsolt János: A magyar büntetés-végrehajtás nemzetbiztonsági aspektusai. Terror \& Elhárítás, 7 (2018), 1. 45-71.

21 Nagy Zsolt: Változások a katasztrófavédelmi képzésben. Védelem Online: Tüz- és Katasztrófavédelmi Szakkönyvtár, (2016), 744. 1-11.

22 Magasvári Adrienn - Szabó Andrea: A Nemzeti Adó- és Vámhivatal munkaerő-megtartó képességének vizsgálata egy speciális célcsoport körében. Magyar Rendészet, 19. (2019), 2-3. 143-162; Ákos Erdős - Adrienn Magasvári - Andrea Szabó: Professional career choice and career start in regards to the expectations of hungarian law enforcement higher education and of the law enforcement organs. Internal Security, 12. (2020), 2. 319-330; Erdős Ákos - Magasvári Adrienn - Szabó Andrea: Új generáció a rendészeti felsőoktatásban. In Gaál Gyula - Hautzinger Zoltán (szerk.): Gondolatok a rendészettudományról: Írások a Magyar Rendészettudományi Társaság megalapításának tizenötödik évfordulója alkalmából. Budapest, Magyar Rendészettudományi Társaság, 2019. 89-102.

23 Kovács István: Egy valós kihívás: toborzás vezetői szemmel. Avagy hogyan tehető vonzóbbá a rendőri hivatás a pályaválasztás előtt álló Z generáció számára? Rendôrségi Tanulmányok, 2. (2019), 2. 75-138.

24 Kovács Gábor: A Nemzeti Közszolgálati Egyetem, mint a közszolgálati képzés bázisa; a jelenlegi helyzetkép, jövőbeni változások, fejlődési tendenciák és kihívások. Pécsi Határőr Tudományos Közlemények, 13. (2012), 371-378; Magasvári-Szabó (2019): i. m. 
adataiból világosan kitűnik, hogy a korábban említett rendészeti humánpolitikai kihívások az NKE RTK-t érintően is kirajzolódnak. Az elmúlt közel egy évtizedben ugyanis mintegy harmadára esett vissza a rendészeti felsőoktatási képzés nappali munkarendű szakirányaira történő jelentkezések száma. Ezzel egyidejüleg a képzés egyes szakirányain jelentős mértékben visszaestek a felvételi ponthatárok is, ami a minőségbiztosítás, a megfelelő alapokkal rendelkező, felkészült utánpótlás biztosítása szempontjából kiemelt jelentőségü. ${ }^{25} \mathrm{Az}$ NKE RTK képzéseire történő toborzást egyebek mellett társadalmi és gazdasági körülmények is nehezítik. Egyfelől Magyarország demográfiai folyamatait vizsgálva megállapítható, hogy a felsőoktatás szempontjából releváns társadalmi korcsoport létszáma az ezredforduló után radikálisan csökkent, és ezen a téren 2050-ig legfeljebb stagnálás prognosztizálható. ${ }^{26}$ Mindezek természetesen a hazai felsőoktatás teljes utánpótlási rendszerére kihatással vannak. A rendészeti képzés utánpótlásának biztosítása tekintetében további nehezítő tényezőként jelenik meg az alkalmassági szűrővizsgálatok kötelező rendszere, amely bár érthető módon szükségszerű, de praktikusan - fizikai, egészségügyi, pszichikai standardok felállításával - szúkíti a toborzás kereteit. Az NKE RTK elmúlt közel egy évtizedes felvételi adatait áttekintve megállapítható, hogy a behívott fiatalok tekintélyes hányada az alkalmassági vizsgákon meg sem jelenik, illetve azokon egyszerűen alkalmatlan minősítést szerez. ${ }^{27}$ A toborzást nehezítő financiális tényezőként említhető továbbá, hogy a más felsőoktatási intézmények által nyújtott rendszeres hallgatói juttatásokhoz viszonyítva a rendészeti felsőoktatás speciális jogállású hallgatóit (tisztjelölt) megillető ösztöndíj mértéke egyáltalán nem kiemelkedő, annak ellenére, hogy őket az átlag egyetemi hallgatói jogviszonyhoz képest számos többletkötelezettség terheli. Másfelől a tisztjelöltek egyéb kereseti tevékenysége a szigorú jelenléti képzési rendnek, szolgálati feladatoknak és a hallgatói tevékenységen kívüli munkavégzés jogi szabályainak köszönhetően meglehetősen korlátozott.

A rendészeti felsőoktatást (is) érintő másik humánpolitikai kihívás, a megtartás (később pedig pályán tartás) elsősorban az újonnan felszerelő tisztjelölti állományt érintően jelentkezik. Az elmúlt öt évben pályát elhagyó fiatalok motivációjának hátterét vizsgálva korábbi kutatások alapján, ${ }^{28}$ a tisztjelöltek a képzés megkezdését követően rövid időn belül bekövetkező pályaelhagyást motiváló tényezőket (leszerelési okokat) öt csoportba sorolhatjuk:

- alacsony kötelezettségtűrés, vagyis azok az indokok, amelyek a tisztjelölti jogállás vagy a rendészeti hivatás jellegzetességeiből fakadó kötelezettségek elutasításával állnak kapcsolatban;

\footnotetext{
25 Christián László - Erdős Ákos: Vészharang és jubileum? A rendészeti felsőoktatás kilátásai, a tisztjelöltek toborzásának és életpályára állításának nehézségei. Belügyi Szemle, 68. (2020), 12. 11-42.

26 Polónyi István: A hazai felsőoktatás demográfiai összefüggései a 21. század elején. Budapest, Felsőoktatási Kutatóintézet, 2004.

27 Christián-Erdős (2020): i. m.

28 Erdős Ákos: A rendészeti tisztté válás első nehézségei - A gyermeki elképzelések találkozása a realitással. Új Pedagógiai Szemle, 69. (2019), 1-2. 76-99; Christián-Erdős (2020): i. m.
} 
- pályatévesztés, vagyis azok az indokok, amelyek a tisztjelölt pályaválasztással kapcsolatos átgondolatlan vagy más által (például szülő) jelentősen befolyásolt, illetve téves elképzeléseken alapuló döntéséből származnak;

- személyes túlvállalás, azok az indokok tartoznak e csoportba, amelyekben a tisztjelölt saját fizikai, illetve pszichés teherbírását vagy tanulási képességeinek megfelelő potenciálját vonja kétségbe;

- egészségügyi alkalmatlanság, amikor a tisztjelöltet valamilyen korábbi sérülés tüneteinek kiújulása vagy pedig a képzésen szerzett sérülés akadályozza a kiképzés befejezésében;

- egyéb indok, idetartozik minden olyan távozást motiváló tényező, amelyet az előbbiekben nem nevesítettünk.

$\mathrm{Az}$ egyik Magyarországon végzett, tisztjelölteket és rendészeti vezetőket egyaránt vizsgáló kvalitatív kutatás eredményei rámutatnak arra, hogy a rendészeti felsőoktatásba érkező hallgatók bevonzásával és megtartásával kapcsolatos kihívásokra reagáló „lehetséges megoldások forrásai több irányból, területről erednek, amelyek egymással szoros kapcsolatban állnak: egyéni dimenzió, intézményi dimenzió, valamint társadalompolitikai dimenzió”. ${ }^{29}$ Ezek alapján úgy tűnik, a rendészeti felsőoktatást illető sikeres toborzás és megtartás megköveteli a fiatal generáció tájékozottságát, reális önértékelését, valamint autonómiája részbeni korlátozásának, a hierarchikus rendnek az elfogadását. Másfelől elfogadó, nyitott, változásra hajlandó közeg biztosítását várja az idősebb generációtól, illetve fontos szellemi, gazdasági és erkölcsi támogatást követel a képzési intézményektől és a politikai döntéshozóktól.

A rendészeti utánpótlás folytonosságának biztosítása érdekében célszerű kiemelt figyelmet fordítani a partneriskolai hálózat kiépítésére. A képzéssel kapcsolatos tájékoztatásokba indokolt bevonni a fiatalok szüleit, akik - kutatási eredmények szerint - komoly hatással vannak ugyanis gyerekeik pályaválasztására. Elengedhetetlen a tisztjelöltek pénzügyi önállóságát támogató, megfelelő anyagi elismerést biztosító ösztöndíjrendszer megalkotása is. Továbbá, hogy a képzés népszerúsítése kapcsán a rendészeti szervek toborzó egységei mellett elsősorban az olyan újszerű kommunikációs felületekre kell koncentrálni, amelyeken keresztül a fiatalok jelentős része elérhető.

A rendészeti felsőoktatásra a fentiek mellett számos további kihívás is vár, a teljesség igénye nélkül kiemelésre érdemes még az oktatás módszereinek teljes körú újragondolása. Manapság olyan fordulóponthoz érkeztünk a felsőoktatásban, amikor nem halogatható a változtatás, különben alulmaradunk az egyik legfontosabb harcban, ez pedig maga az oktatás.

Erdős Ákos et al.: NAV Café - A Nemzeti Adó- és Vámhivatal személyi állományának utánpótlása, felkészítésük gyakorlati kérdései. Magyar Rendészet, 20. (2020), 1. 153. 
„A jelenlegi tudásunk alapján már látszik, hogy az oktatásnak/oktatóknak igazodnia kell azon új igényekhez, melyek főleg a $Z$ generáció viselkedési jellemzőinek ismeretében kirajzolódnak. A generációk eltérő szocializációja, identifikációja kiegészül azzal, hogy míg az oktatók poroszos tekintélytiszteletben szocializálódtak, az alkalmazkodást és az idősebb tekintélyszemély dominanciáját egyértelműen elfogadták/ elfogadják, addig most olyan diákokkal találkoznak, akik már az információs társadalom tagjai. Ez utóbbi megállapítás azt jelenti, hogy a tekintély és tisztelet fogalmai felülíródtak, a fordított szocializáció értelmében már nem gondolják, hogy az idősebb ember a tudás letéteményese. Ez azonban jelentősen megváltoztatja az oktatással kapcsolatos kívánatos attitűdöt, és azt eredményezi, hogy az oktatásnak rugalmasabbá, az oktatói magatartásnak hitelesebbé kell válnia. Ez érzelmi és értelmi erőfeszítést is igénylő feladat, ami gyakran hozhat létre konfliktushelyzeteket."30

Az NKE küldetésének tehát arra is ki kell terjednie, hogy a képzéseink a fokozódó versenyben egyre vonzóbbak legyenek, meg kell nyernünk a Z majd az alfa generáció tagjait és vonzó tartalmat (képzést) és perspektívát kell tudni felkínálni számukra. Az Egyetemünk által meghirdetett Kreatív Tanulás Program céljainak elérése érdekében az alábbiakra van szükség:

- a közös tanulást vezető és az egyéni alkotómunkát mentoráló tanári tevékenység;

- a tömegoktatás helyett kiscsoportos képzés (személyes tanár-diák kapcsolat);

- a hallgatók tudásának értékelése a szorgalmi időszakban végzett közösségi és egyéni kreatív munkák alapján;

- magolás helyett a kulcsképességek fejlesztése, tehetség kibontása.

Szent-Györgyi Albert szavai iránytűként szolgálhatnak számunkra ebben a fentiekben ecsetelt összetett vállalkozásban a rendészeti felsőoktatásban:

„Az iskola dolga, hogy megtaníttassa velünk, hogyan kell tanulni, hogy felkeltse a tudás iránti étvágyunkat, hogy tanítson minket a jól végzett munka örömére és izgalmára, hogy megtanítson szeretni, amit csinálunk, és hogy segítsen megtalálni azt, amit szeretünk csinálni."

\section{Összefoglalás}

A rendészeti felsőoktatás a Nemzeti Közszolgálati Egyetem megalakulása óta hasonlóan jelentős változáson és fejlődésen ment keresztül, mint az azt megelőző négy évtizedben. Az oktatásért felelős intézmény egykori szakfőiskolai státuszából mára 30 Nádasi András - Tari Annamária - Szander Ágnes (kutatásvezető: Sabjanics István): A net-generációk tanulási jellemzố-
inek és az oktatók digitális kompetencia mutatóinak kvalitatív vizsgálata 2018-2020. 
egyetemi szintű karrá fejlődött, amely nemcsak a magyar rendőr- és más rendvédelmi hivatásrendek tisztképzéséért felel, hanem meghatározó részévé vált az azt befogadó egyetemi környezetnek és minőségnek. Ez egyrészt köszönhető a kart alkotó oktatói közösségnek, akik felismerték a változtatás igényét és az egyetemi integrációból adódó lehetőségeket, másfelől mindannak az infrastrukturális fejlődésnek, amely a 21. század második évtizedében támogatta a rendészeti tisztképzést. A kar állománya napjainkban olyan egységet alkot, amely a kutatást, az oktatást és a hallgatók nevelését, kiképzését alapfeladatának tekinti. A kar vezetésének célja a képzéseket megrendelő Belügyminisztérium képzési igényeinek teljesítése úgy, hogy azok megfeleljenek a 21. századi generációs kihívásoknak és a kor követelményeinek.

\section{FELHASZNÁLT IRODALOM}

Bartos László: Gondolatok a rendészeti oktatásról. Rendészeti Szemle, 57. (2009), 3. 3-15.

Christián László - Erdős Ákos: Vészharang és jubileum? A rendészeti felsőoktatás kilátásai, a tisztjelöltek toborzásának és életpályára állításának nehézségei. Belügyi Szemle, 68. (2020), 12. 11 42. Online: https://doi.org/10.38146/BSZ.2020.12.1

Christián László: A helyi rendészeti együttmúködés rendszere. Iustum Aequum Salutare, 14. (2018), 1. 33-61. Online: http://ias.jak.ppke.hu/hir/ias/20181sz/03_ChristianL_IAS_2018_1.pdf

Erdős Ákos - Magasvári Adrienn - Molnár Katalin - Pócsi Anikó - Szabó Andrea - Vas Adrienn: NAV Café - A Nemzeti Adó- és Vámhivatal személyi állományának utánpótlása, felkészítésük gyakorlati kérdései. Magyar Rendészet, 21. (2020), 1.149-177. Online: https://doi.org/10.32577/ mr.2020.1.10

Erdős Ákos - Magasvári Adrienn - Szabó Andrea: Új generáció a rendészeti felsőoktatásban. In Gaál Gyula - Hautzinger Zoltán (szerk.): Gondolatok a rendészettudományról: Írások a Magyar Rendészettudományi Társaság megalapitásának tizenötödik évfordulója alkalmából. Budapest, Magyar Rendészettudományi Társaság, 2019. 89-102. Online: http://real.mtak.hu/93732/1/ MRTT15.pdf

Erdős Ákos: A rendészeti tisztté válás első nehézségei - A gyermeki elképzelések találkozása a realitással. Új Pedagógiai Szemle, 69. (2019), 1-2. 76-99.

Erdős, Ákos - Adrienn Magasvári - Andrea Szabó: Professional career choice and career start in regards to the expectations of hungarian law enforcement higher education and of the law enforcement organs. Internal Security, (2020), 2. 319-330. Online: https://10.5604/01.3001.0014.6702

Eurostat: Police, court and prison personnel statistics. Eurostat, 2020. Online: https://ec.europa.eu/ eurostat/statistics-explained/index.php?title=Police, _court_and_prison_personnel_statistics\&oldid $=456867$

Ewijk, Anne R. van: Diversity within Police Forces in Europe: A Case for the Comprehensive View. Policing, 6. (2011), 1. 76-92. Online: https://doi.org/10.1093/police/par048

Kerezsi Klára - Pap András László: Rendészet, tudomány, doktori iskola. Magyar Rendészet, 15. (2015), 4. 67-83. Online: https://folyoirat.ludovika.hu/index.php/magyrend/article/ view/3644/2927

Kiskopárdi Zsolt János: A magyar büntetés-végrehajtás nemzetbiztonsági aspektusai. Terror \& Elhárítás, 7. (2018), 1. 45-71. Online: http://epa.oszk.hu/02900/02932/00016/pdf/EPA02932_ terror_elharitas_2018_1.pdf 
Kovács Gábor: A Nemzeti Közszolgálati Egyetem, mint a közszolgálati képzés bázisa; a jelenlegi helyzetkép, jövőbeni változások, fejlődési tendenciák és kihívások. Pécsi Határőr Tudományos Közlemények, 13. (2012), 371-378. Online: www.pecshor.hu/periodika/XIII/kovacsg.pdf

Kovács Gábor: Tájékoztató a Nemzeti Közszolgálati Egyetem megalakulásáról és működéséről. Migráció és Társadalom, (2012).

Kovács István: Egy valós kihívás: toborzás vezetői szemmel. Avagy hogyan tehető vonzóbbá a rendőri hivatás a pályaválasztás előtt álló $Z$ generáció számára? Rendőrségi Tanulmányok, 2. (2019), 2. 75-138. Online: www.bm-tt.hu/rtt/assets/letolt/rt/201902/04_Kovacs_Istvan. pdf

KSH: Népesedési világnap, 2019. július 11. Statisztikai Tükör, Budapest, Központi Statisztikai Hivatal (2019. július 11.). Online: www.ksh.hu/docs/hun/xftp/stattukor/nepesedesi19.pdf

Magasvári Adrienn - Szabó Andrea: A Nemzeti Adó- és Vámhivatal munkaerő-megtartó képességének vizsgálata egy speciális célcsoport körében. Magyar Rendészet, 19. (2019), 2-3. 143162. Online: https://doi.org/10.32577/mr.2019.2-3.8

Morison, Kevin P.: Hiring for the $21^{\text {st }}$ century law enforcement officer: Challenges, opportunities, and strategies for success. Washington, D.C., Office of Community Oriented Policing Services, 2017. Online: https://cops.usdoj.gov/RIC/Publications/cops-w0831-pub.pdf

Nagy Zsolt: Változások a katasztrófavédelmi képzésben. Védelem Online: Túz- és Katasztrófavédelmi Szakkönyvtár, (2016), 744.1-11.

Nádasi András - Tari Annamária - Szander Ágnes (kutatásvezető: Sabjanics István): A net-generációk tanulási jellemzőinek és az oktatók digitális kompetencia mutatóinak kvalitatív vizsgálata 2018-2020. Online: www.bm-tt.hu/assets/letolt/kutat/2020/Genkutat.pdf

Office of Community Oriented Policing Services: Deliberative and pre-decisional. Chapter 2. Law enforcement recruitment and training. Washington D.C., The United States Department of Justice, 2020. Online: www.justice.gov/file/1354581/download

Police Executive Research Forum: The workforce Ccrisis, and what police agencies are doing about it. Washington D. C. (September 2019). Online: www.policeforum.org/assets/WorkforceCrisis.pdf

Polónyi István: A hazai felsőoktatás demográfiai összefüggései a 21. század elején. Budapest, Felsőoktatási Kutatóintézet, 2004.

Sallai János: A magyar rendészettudomány akkreditációja. Belügyi Szemle, (2019), 10. 7-23. Online: https://doi.org/10.38146/BSZ.2019.10.1

Vári Vince: A rendőri életpályamodell és a rendőri felsőoktatás összehangoltsága. Magyar Rendészet, 18. (2018), 2. 205-222. Online: https://folyoirat.ludovika.hu/index.php/magyrend/article/view/1372/699

Virányi Gergely: Határrendészeti tisztképzés a Rendőrtiszti Főiskolán, 1971-2011. Budapest, Dialóg Campus, 2019.

Wilson, Jeremy M. - Clifford A. Grammich: Police recruitment and retention in the contemporary urban environment. Santa Monica, CA, RAND Corporation, 2009. Online: www.rand.org/pubs/conf_ proceedings/CF261.html

\section{Jogi források}

2011. évi XXXVI. törvény a Nemzeti Közszolgálati Egyetem létesítéséről

Nemzeti Közszolgálati Egyetem Szervezeti és Működési Szabályzat. Online: www.uni-nke.hu/ index.php/hu/szabalyzatok-dokumentumok/104-szmsz 


\section{ABSTRACT}

The Present and Future of the Hungarian Law Enforcement Higher Education László CHRISTIÁN - Zoltán HAUTZINGER - Gábor KOVÁCS

With the establishment of the University of Public Service, law enforcement training at the Faculty of Law Enforcement has taken on a new dimension, and its development is continuous and well tracked. The essay briefly describes the bachelor and master degree programmes in law enforcement, their current status and prospects, and also highlights initiatives that are seeking to set new directions for law enforcement higher education in a comprehensive manner.

Keywords: Faculty of Law Enforcement, Law Enforcement higher education, Law Enforcement officer education 